\title{
Dynamics of cyanobacteria-ciliate grazer activity in bitrophic and tritrophic microcosms
}

\author{
Janusz Fyda*, Edyta Fiałkowska, Agnieszka Pajdak-Stós
}

Institute of Environmental Sciences, Jagiellonian University, Gronostajowa 7, 30-387 Kraków, Poland

\begin{abstract}
Direct and indirect interactions among components of bitrophic and tritrophic communities were studied using laboratory microcosms. The filamentous cyanobacterium Phormidium sp. capable of inducible defence, was used as the primary producer. Phormidium reacts to ciliate attacks by withdrawing inside a polysaccharide envelope, overproducing exopolysaccharide material and remaining in dense and compact clumps. All of these defences are induced by the ciliate Pseudomicrothorax dubius, a specialised grazer of filamentous cyanobacteria, representing the second trophic level in our system. The gymnostomatid ciliate Homalozoon vermiculare, which preys on Pseudomicrothorax but does not directly affect cyanobacteria, was the top predator within the microcosm community. The experiment showed that Homalozoon, very effective in a simple bitrophic cascade, had little effect on its prey when Phormidium was introduced into the system. Under grazer pressure, the cyanobacterium defended itself against the grazer by creating clumps of entangled filaments that also served as refuges for Pseudomicrothorax from Homalozoon. The prey ciliate Pseudomicrothorax reacts to cyanobacterial defence by increasing its encystation rate. Gradually decreasing grazing pressure resulted in a diminished Phormidium defence reaction, which enabled Pseudomicrothorax to resume feeding on filaments. Changing the extent of induced defence in Phormidium thus resulted in the stabilisation of the microcosm community.
\end{abstract}

KEY WORDS: Ciliated protozoa · Homalozoon · Induced defence · Phormidium · Predator-prey interactions $\cdot$ Pseudomicrothorax

\section{INTRODUCTION}

In temporary freshwater ecosystems, microorganisms such as cyanobacteria and ciliated protozoa are the main components of the aquatic microbial community. Their ecological functions, along with predatorprey interactions, have been well studied (e.g. Gasol \& Duarte 2000, Wiąckowski et al. 2001, Ventelä et al. 2002, Pinckney et al. 2003, Samuelsson \& Andersson 2003); however, the detailed links among different components of trophic cascades remain for the most part unclear. In both laboratory microcosms and natural ecosystems, direct predator-prey interactions evoke oscillations in predator and prey abundances. These predator-prey abundances, which depend on experimental design or ecosystem properties, usually lead to prey population decrements or prey extinction (e.g. Gause 1934, Salt 1967, Luckinbill 1973, Veilleux 1979). Under conditions of food shortage, the predator population may decrease or even completely disappear. Most ecologists agree that the trophic cascade in a variety of ecosystems is a balance between bottomup and top-down control (Brett \& Goldman 1996, Halaj \& Wise 2002, Shurin et al. 2002, 2006). The role of the predator in a food web can be complicated by prey heterogeneity (Bohannan \& Lenski 2000, Steiner 2001) or by the availability of prey representing alternative trophic levels (Balčiünas \& Lawler 1995, Kołaczyk \& Wiąckowski 1997). Bohannan and Lenski (1997) observed that the invasion of a model laboratory community by bacteriophage-resistant mutants of Escherichia coli subjected to bacteriophage T4 had a strong effect on the subsequent population dynamics of both predator and prey. Both the equilibrium density 
and stability of the E. coli population increased following the invasion. Kołaczyk and Wiąckowski (1997) showed reduced predation on ciliate Euplotes octocarinatus by Stylonychia mytilus in the presence of an abundant green flagellate population, which served as alternative food for the predator. Trophic cascade interactions are also modified when the prey has access to refuges (Křivan 1998) or activates predatorinduced defences (Fiałkowska \& Pajdak-Stós 1997, Fyda 1998, Tollrian \& Harvell 1999, Pajdak-Stós et al. 2001). These predator-induced defences include adaptive prey behaviours, such as predator avoidance reactions or escape responses, as well as the use of refuges that make prey less susceptible to predator attacks and consequently, reduce predator-prey oscillations. In addition, low refuge carrying capacity leads to stability of predator-prey dynamics, while stability is lost when the carrying capacity of the refuge is high (Křivan 1998). In the presence of their predators, some ciliates reveal induced defences consisting of cell shape changes, as in the case of Colpidium (Fyda 1998), or develop additional spines, as in Onychodromus quadricornutus and Aspidisca turrita (Wicklow 1997). Likewise, in the presence of their predators, several Euplotes species enlarge cell width and develop dorsal spines. The induced morphotype stands a better chance of avoiding the predator attack and a higher probability of survival in the predator's presence (Kuhlman \& Heckmann 1994, Kusch 1995, Fyda \& Wiąckowski 1998, Altwegg et al. 2006). An interesting example of induced defence in filamentous cyanobacteria was discovered by Fiałkowska and Pajdak-Stós (1997). In the presence of the ciliate Pseudomicrothorax dubius, which is specialised for ingesting filaments, cyanobacterium Phormidium sp. reacts to a ciliate attack by withdrawing inside a polysaccharide sheath where the filament is inaccessible to grazers. Moreover, instead of dispersing as in ciliate-free controls, in the presence of Pseudomicrothorax, cyanobacteria filaments entangle in dense and compact clumps, surrounded by a layer of exopolysaccharides, which further protects them from attack (Fiałkowska \& Pajdak-Stós 1997, 2002, Pajdak-Stós et al. 2001).

Induced defence, widespread in both terrestrial and aquatic ecosystems, has broader impacts on the community than mere prey survival (Tollrian \& Harvell 1999, Gomez \& Zamora 2002). As discovered recently, it also affects other direct and indirect interactions among community components (Van der Stap et al. 2006, 2007a,b, 2008). Induced defences decrease per capita consumption rates of predators and increase the relative importance of bottom-up control (Vos et al. 2004a). These defences also promote population persistence and stability in simple bitrophic and tritrophic food chains (Verschoor et al. 2004, Vos et al. 2004b, Fyda et al. 2009). Moreover, inducible defence causes an absence of the 'paradox of enrichment', which in simple food chains leads to destabilisation of the predator population (Rosenzweig 1971, Vos et al. 2004b).

The present study examined the changes in tritrophic levels of microcosm communities composed of an autotrophic producer, its ciliate consumer and a top ciliate predator. Our aim was to study how the predacious ciliate affects prey ciliate abundance and activity, and how Phormidium predator-induced defences affect predator-grazer mediated coexistence.

\section{MATERIALS AND METHODS}

Cultures. All microorganisms used in this study are common species in freshwater puddles and ponds and coexist in nature. As a primary producer, we used the filamentous cyanobacterium (C) Phormidium sp. (described by Fiałkowska \& Pajdak-Stós 1997). The second trophic level (P1) was represented by Pseudomicrothorax dubius, which is a specialised grazer of filamentous cyanobacteria. The top predator (P2) used in some treatments was the gymnostomatid ciliate Homalozoon vermiculare. Both ciliate species used in the experiment were taken from clone populations maintained at the Institute of Environmental Sciences, Jagiellonian University, Kraków, Poland. Hereafter, we refer to the species by their generic names. The strain of Phormidium and the clone of Pseudomicrothorax were obtained from single filaments/cells isolated from a freshwater aquarium filled with pond water, and Homalozoon was isolated from a puddle. The pond and the puddle were located near the university campus on wetlands $\left(50^{\circ} 01^{\prime} 34^{\prime \prime} \mathrm{N}, 19^{\circ} 54^{\prime} 05^{\prime \prime} \mathrm{E}\right)$.

Prior to the experiment, clones of the ciliates and Phormidium were cultivated in $5 \mathrm{~cm}$ diameter Petri dishes in Sanyo MLR-350 versatile environmental test chambers at a constant temperature of $20^{\circ} \mathrm{C}$. The dishes contained BG11 medium (Stanier et al. 1971) prepared according to a formula obtained from the Culture Collection of Algae and Protozoa (CCAP, Ambleside, UK). The cultures of Phormidium were kept at a light intensity of $70 \mu \mathrm{mol}$ photon $\mathrm{m}^{-2} \mathrm{~s}^{-1}$ under a $12: 12 \mathrm{~h}$ light:dark cycle at $20^{\circ} \mathrm{C}$. The ciliate cultures were kept in constant darkness. Twice a week, the clone of Pseudomicrothorax was fed Phormidium filaments, whereas the clone of Homalozoon was fed ciliate Colpidium colpoda. About $100 \mu \mathrm{l}$ of dense Colpidium culture was added by micropipette to the Petri dishes containing Homalozoon every $2 \mathrm{~d}$.

Experimental design and sampling regime. A microcosm experiment was carried out in crosscombinations of the presence or absence of the ciliate predator Homalozoon. The microcosms were estab- 
lished in 24-well polystyrene tissue culture test plates (Renner $\mathrm{GmbH}$ ). Each well contained $1 \mathrm{ml}$ of BG11 medium. Approximately equal-sized $(1 \times 1 \mathrm{~mm})$ pieces cut from the Phormidium mat were added to 12 wells. The presence of Phormidium in the treatments is marked by the symbol $\mathrm{C}$. The wells were divided into 4 groups: to the first $(\mathrm{C}+\mathrm{P} 1+\mathrm{P} 2), 100$ Pseudomicrothorax individuals and 5 Homalozoon individuals were added to each well; to the second $(\mathrm{C}+\mathrm{P} 1), 100$ Pseudomicrothorax individuals were added; the third $(\mathrm{C}+\mathrm{P} 2)$ contained 5 Homalozoon cells per well, and the fourth (P1 + P2) contained 100 Pseudomicrothorax and 5 Homalozoon cells. As a control (C), we used wells containing only Phormidium mat. A second control (P1), containing only 100 Pseudomicrothorax individuals in $1 \mathrm{ml}$ of BG11 medium, was also established. All ciliates were individually transferred with a pipette from their culture dishes to the experimental wells. Four replicates of every experimental treatment and control were made. Experimental plates were placed in a climate chamber and kept at $20^{\circ} \mathrm{C}$ at a light intensity of $70 \mu \mathrm{mol}$ photon $\mathrm{m}^{-2} \mathrm{~s}^{-1}$ under a 12:12 h light:dark cycle. The experiment lasted $7 \mathrm{~d}$. During this period, all experimental wells were checked under an inverted Olympus IX 71 microscope at 40× after 2 h (Day 0), then after 2, 6 and $7 \mathrm{~d}$. During those surveys, the bottom of each well was scanned systematically and Pseudomicrothorax were counted using the following categories: well-fed with green vacuoles, active and dead cells. During the microscope surveys, ciliate cysts were also counted using 2 categories: full cysts with a ciliate inside and empty cyst walls remaining after excystment, referred to as empty cysts. Neither dead/ paralyzed (by predator) Pseudomicrothorax individuals nor their cysts were removed from the wells. After $2 \mathrm{~h}$ and after 3 and $6 \mathrm{~d}$, the percentage of Phormidium filaments ending with polysaccharide sheaths was calculated from 100 randomly chosen filament endings along the edge of the mat. At the end of the experiment, a $10 \times$ reference image of every treatment well was recorded with a DP70 microscope digital camera attached to the microscope in order to evaluate the condition of the cyanobacteria mat.

Statistical analysis. We used repeated-measures analysis of variance (ANOVA) to estimate the effects of Homalozoon presence on Pseudomicrothorax abundance and activity during the experiment. The presence of the top predator (P2) and cyanobacteria (C) and the interactions between the 2 were used as betweentreatment factors and consecutive days in the experiment were used as a within-subject factor. To avoid non-linearity of percentage values, the arcsine transformation was used (Sokal \& Rohlf 1981). All statistical analyses were performed using the data analysis software system STATISTICA StatSoft (2007), version 8.0.

\section{RESULTS}

\section{Effects of Homalozoon on Pseudomicrothorax}

On Day 0, the mean number of active Pseudomicrothorax per well ranged from $18 \pm 5$ (mean \pm SD here and elsewhere) in pure BG11 medium (P1 treatment) to $23 \pm 5$ on average in all other treatments that day (Fig. 1). The number of active Pseudomicrothorax individuals varied significantly between treatments on consecutive days (Fig. 1). In $\mathrm{C}+\mathrm{P} 1+\mathrm{P} 2$, the number increased significantly on the second day of the experiment, and remained at a similar level until the end of experiment. A similar effect was observed in $\mathrm{C}+\mathrm{P} 1$ where Homalozoon was absent. The ciliate predator significantly affected the abundance of Pseudomicrothorax only in $\mathrm{P} 1+\mathrm{P} 2$ where no cyanobacteria were present. In this treatment, the number of active Pseudomicrothorax rapidly decreased, and no active ciliates were observed after the second day. This predation effect was significant (repeated-measures ANOVA, p < 0.003), and almost all prey ciliates were paralysed or ingested by Homalozoon. Similar results, though much later in the experiment, were observed in the P1 treatment with only Pseudomicrothorax in BG11 medium: after a small increase in the number of active cells on the second day, the number of Pseudomicrothorax decreased and no active cells were observed at the end of experiment (Fig. 1). The statistical significance of the results is shown in Table 1.

The mean percentage of well-fed Pseudomicrothorax per experimental well remained at a similar level throughout the experiment in the $\mathrm{C}+\mathrm{P} 1+\mathrm{P} 2$ treatment, ranging from $74 \pm 13 \%$ at the beginning to $95 \pm 4.6 \%$ after $1 \mathrm{wk}$. In the C+P1 treatment, well-fed Pseudomi-

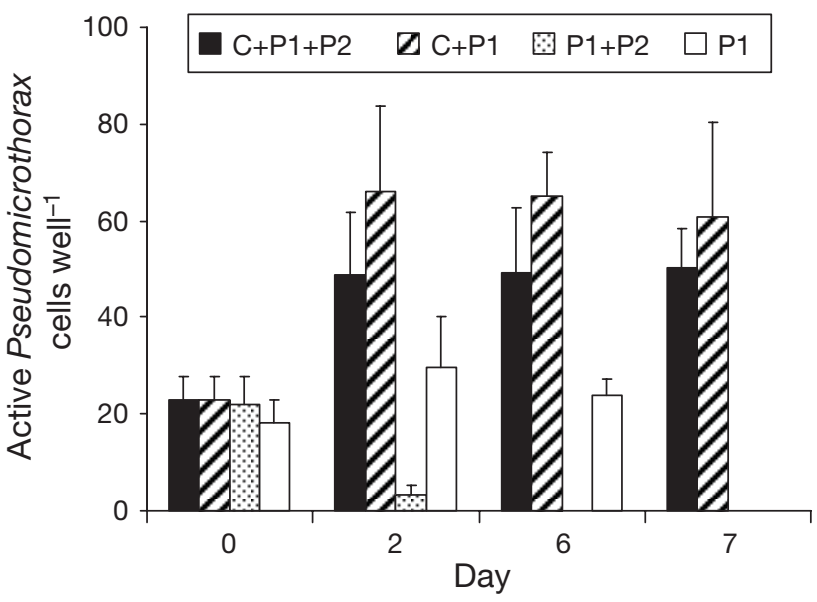

Fig. 1. Pseudomicrothorax dubius. Changes in the mean (+SD) number of active cells during the experiment. Treatments: P1: Pseudomicrothorax, P2: Homalozoon, C: Phormidium 
Table 1. The results of repeated-measures ANOVA showing effects of Phormidium (C) and Homalozoon (P2) absence/presence on the abundance of the cyanobacteria grazer Pseudomicrothorax in microcosms during the time $(\mathrm{T})$ of the experiment. Significant results are given in bold

\begin{tabular}{|c|c|c|c|c|c|}
\hline State & Source of variation & $\mathrm{df}$ & SS & $F$ & $\mathrm{p}$ \\
\hline $\begin{array}{l}\text { Pseudomicrothorax } \\
\text { well fed cells }\end{array}$ & $\begin{array}{l}\text { Between-treatments } \\
\text { Homalozoon } \\
\text { Error } \\
\text { Within-treatments } \\
\text { Time }(\mathrm{T}) \\
\mathrm{T} \times \mathrm{P} 2 \\
\text { Error }(\mathrm{T})\end{array}$ & $\begin{array}{c}5 \\
5 \\
30\end{array}$ & $\begin{array}{c}2105.6 \\
277.8 \\
1548.7\end{array}$ & $\begin{array}{l}8.16 \\
1.08\end{array}$ & $\begin{array}{c}<\mathbf{0 . 0 0 1} \\
0.393\end{array}$ \\
\hline $\begin{array}{l}\text { Pseudomicrothorax } \\
\text { active cells }\end{array}$ & $\begin{array}{l}\text { Between-treatments } \\
\text { Phormidium } \\
\text { Homalozoon } \\
\mathrm{C} \times \mathrm{P} 2 \\
\text { Error } \\
\text { Within-treatments } \\
\text { Time }(\mathrm{T}) \\
\mathrm{T} \times \mathrm{C} \\
\mathrm{T} \times \mathrm{P} 2 \\
\mathrm{~T} \times \mathrm{C} \times \mathrm{P} 2 \\
\text { Error }(\mathrm{T})\end{array}$ & $\begin{array}{c}3 \\
3 \\
3 \\
3 \\
36\end{array}$ & $\begin{array}{c}2333.05 \\
6418.67 \\
1525.17 \\
283.30 \\
2600.56\end{array}$ & $\begin{array}{c}152.54 \\
14.64 \\
0.0137\end{array}$ & $\begin{array}{c}<0.001 \\
<\mathbf{0 . 0 0 1} \\
<\mathbf{0 . 0 0 1} \\
0.287\end{array}$ \\
\hline $\begin{array}{l}\text { Pseudomicrothorax } \\
\text { dead cells }\end{array}$ & $\begin{array}{l}\text { Between-treatments } \\
\text { Phormidium } \\
\text { Homalozoon } \\
\mathrm{C} \times \mathrm{P} 2 \\
\text { Error } \\
\text { Within-treatments } \\
\text { Time }(\mathrm{T}) \\
\mathrm{T} \times \mathrm{C} \\
\mathrm{T} \times \mathrm{P} 2 \\
\mathrm{~T} \times \mathrm{C} \times \mathrm{P} 2 \\
\text { Error }(\mathrm{T})\end{array}$ & $\begin{array}{c}5 \\
5 \\
5 \\
5 \\
60\end{array}$ & $\begin{array}{c}73.50 \\
4.17 \\
10.67 \\
87.50 \\
\\
201.33 \\
159.00 \\
60.83 \\
79.83 \\
165.00\end{array}$ & $\begin{array}{c}14.64 \\
11.56 \\
4.24 \\
5.81\end{array}$ & $\begin{array}{l}<0.001 \\
<0.001 \\
<0.002 \\
<0.001\end{array}$ \\
\hline $\begin{array}{l}\text { Pseudomicrothorax } \\
\text { cysts }\end{array}$ & $\begin{array}{l}\text { Between-treatments } \\
\text { Phormidium } \\
\text { Homalozoon } \\
\mathrm{C} \times \mathrm{P} 2 \\
\text { Error } \\
\text { Within-treatments } \\
\text { Time }(\mathrm{T}) \\
\mathrm{T} \times \mathrm{C} \\
\mathrm{T} \times \mathrm{P} 2 \\
\mathrm{~T} \times \mathrm{C} \times \mathrm{P} 2 \\
\text { Error }(\mathrm{T})\end{array}$ & $\begin{array}{c}8 \\
8 \\
8 \\
8 \\
96\end{array}$ & $\begin{array}{c}135792.3 \\
950.7 \\
1600.0 \\
7579.6 \\
\\
245128.0 \\
256393.1 \\
2769.9 \\
2612.9 \\
16069.4\end{array}$ & $\begin{array}{c}183.052 \\
191.465 \\
2.069 \\
1.951\end{array}$ & $\begin{array}{c}<0.001 \\
<\mathbf{0 . 0 0 1} \\
<\mathbf{0 . 0 5} \\
0.06\end{array}$ \\
\hline
\end{tabular}

Phormidium significantly affected cyst formation during the entire experiment (repeated-measures ANOVA, $\mathrm{p}<0.001$ ), whereas Homalozoon did not (repeated-measures ANOVA, p = 0.243). The number of empty cysts remaining after excystment-noticed for the first time on Day 2 - was low in all treatments and differences were not significant (Fig. 2b).

The mean number of dead Pseudomicrothorax cells varied during the experiment depending on the treatment. A few dead cells of Pseudomicrothorax were observed on the second day in the $\mathrm{P} 1+\mathrm{P} 2$ treatment where no Phormidium was added. Over the next few days, the number of dead cells increased significantly in both the $\mathrm{C}+\mathrm{P} 1+\mathrm{P} 2$ and $\mathrm{C}+\mathrm{P} 1$ treatments, whereas they were no longer observed in $\mathrm{P} 1+\mathrm{P} 2$ wells (Fig. 2c). The presence of the cyanobacterium affected the number of dead Pseudomicrothorax, whereas the presence of Homalozoon had no significant effect (repeatedmeasures ANOVA, $\mathrm{p}<0.01, \mathrm{p}=0.464$, respectively).

\section{Effects of Pseudomicrothorax on Phormidium}

The effect of Pseudomicrothorax on cyanobacterial filaments is shown in Fig. 3. In the absence of the grazer, the filaments began to disperse over the bottom of the experimental wells (Fig. 3a). Similar results were observed in wells where only Homalozoon was present (Fig. 3b). The appearance of mats was different in the $\mathrm{C}+\mathrm{P} 1$ and $\mathrm{C}+\mathrm{P} 1+\mathrm{P} 2$ treatments (Fig. 3c,d). Fila-

crothorax comprised $85 \pm 7$ and $93 \pm 7 \%$ of total numbers on Days 0 and 7, respectively, which was not significantly different from that of treatments with Homalozoon.

The mean number of Pseudomicrothorax cysts per well was low in the $\mathrm{C}+\mathrm{P} 1+\mathrm{P} 2$ treatment during the first $2 \mathrm{~d}$ of the experiment, then increased to $165 \pm 24.9$ on Day 6, and did not change significantly on the last day (Fig. 2a). A similar situation was observed in the treatment without the predator $(\mathrm{C}+\mathrm{P} 1)$, where the total number of cysts reached $198.8 \pm 35.7$ and remained at a similar level until the end of the experiment (Fig. 2a). ment dispersion was clearly limited, the effect being more pronounced when there was no predator in the wells (Fig. 3c). In addition, it was clear that the mats under strong Pseudomicrothorax pressure created extremely dense, compact clumps (Fig. 3c), whereas those in the $\mathrm{C}+\mathrm{P} 1+\mathrm{P} 2$ treatment resembled a nest with filaments loosely packed in the centre where active Pseudomicrothorax gathered, and much more densely packed at the edge (Fig. 3d). The impact of Pseudomicrothorax on Phormidium was also reflected in an increasing proportion of filaments ending with empty polysaccharide sheaths (Fig. 4). The highest proportion 

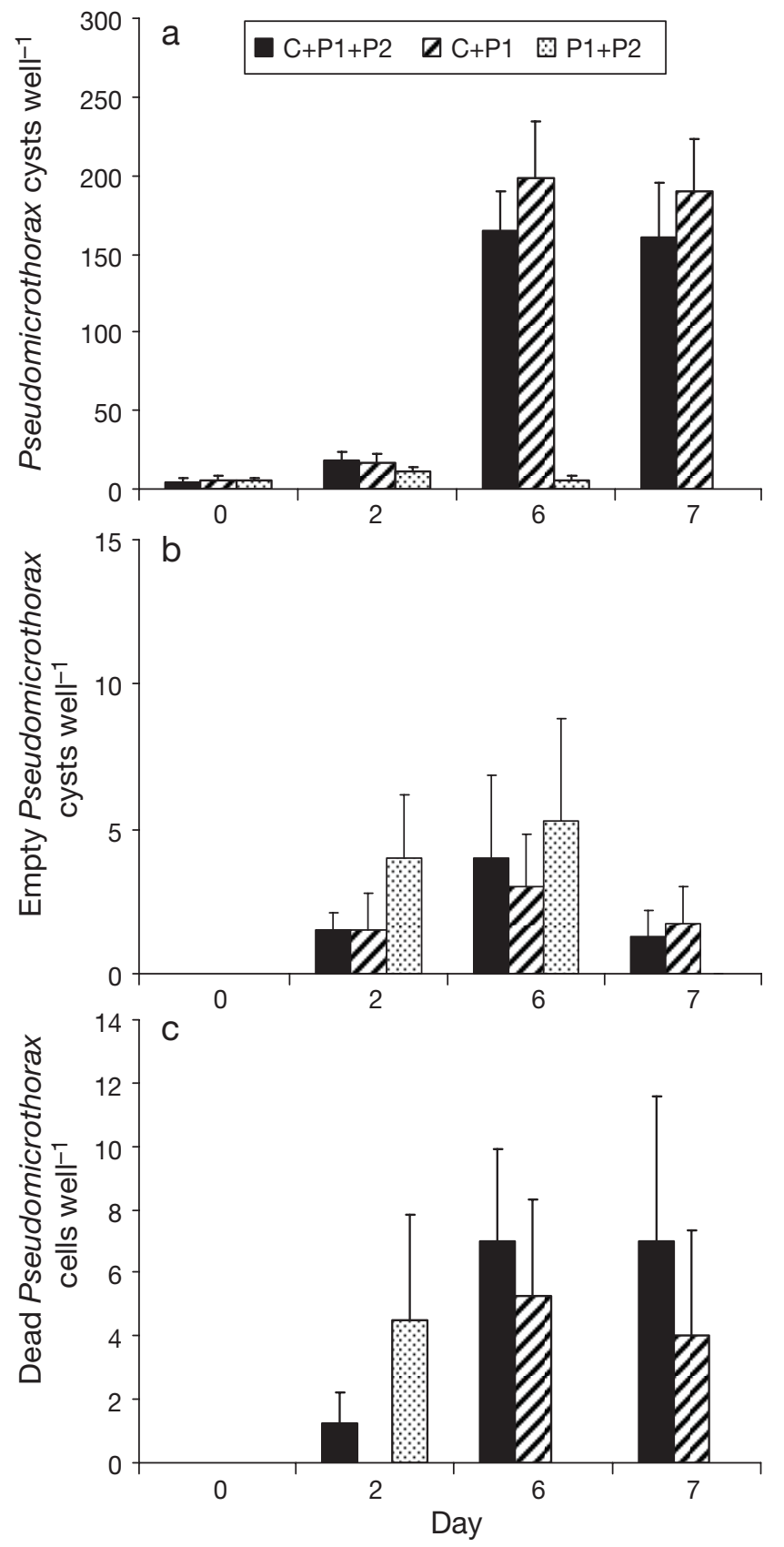

Fig. 2. Pseudomicrothorax dubius. Changes in the mean (+SD) number of (a) all cysts, (b) empty cysts and (c) dead Pseudomicrothorax cells in all treatments during the experiment. Treatments: P1: Pseudomicrothorax, P2: Homalozoon,

$$
\text { C: Phormidium }
$$

of these ends was observed in the wells containing Pseudomicrothorax (C+P1+P2 and $\mathrm{C}+\mathrm{P} 1$ treatments), and was significantly higher (repeated-measures ANOVA, $\mathrm{p}<0.001$ ) than in the $\mathrm{C}+\mathrm{P} 2$ and $\mathrm{C}$ treatments (Table 2). Again, the effect was slightly more pronounced in the $\mathrm{C}+\mathrm{P} 1$ treatment where the cyanobacterial grazer was not controlled by Homalozoon.

\section{DISCUSSION}

\section{Effects of Homalozoon on Pseudomicrothorax activity in bitrophic and tritrophic microcosms}

Predatory pressure plays an important role in ecosystem formation, and predator-prey oscillation patterns depend on ecosystem complexity and functionality (Chase et al. 2002, Strom 2002). In simple bitrophic microcosms, strong predatory pressure often leads to prey extinction in a short period. This is the case when prey is devoid of any kind of refuge or has insufficient time or nutrition resources to defend itself by inducible defences (Tollrian \& Harvell 1999). In our experimental bitrophic microcosms where only Homalozoon and Pseudomicrothorax were present, we observed predatory pressure strong enough to completely eliminate prey, much stronger than in the tritrophic system where the cyanobacterial mat was present. This effect was strengthened by the fact that both predator and prey are bottom-dwelling ciliates and their encounter probability in the experimental wells was very high (Baumberg \& Hausmann 2007). In addition, Homalozoon is a very effective raptorial ciliate feeder, with a peristome armed with toxicysts that paralyze the prey (Foissner et al. 1995).

Our experiments showed how the introduction of another trophic level-Phormidium mats-complicated the system. In the presence of Pseudomicrothorax, Phormidium defends itself against grazing by staying inside dense clumps (Pajdak-Stós et al. 2001). In the wells with Homalozoon, the Phormidium formed 'nest-like' clumps with the central space occupied by Pseudomicrothorax (Fig. 3d). We observed that Pseudomicrothorax took advantage of refuges offered by bundled filaments of cyanobacteria clumps. The cyanobacteria apparently gave Pseudomicrothorax a better chance to survive and even thrive. The lower density of filaments inside the clumps creating the refuge could be the effect of constant grazing pressure by Pseudomicrothorax or a rapid behavioural 'escape' reaction of filaments after ciliate attack (Fiałkowska \& Pajdak-Stós 1997). Contrary to our bitrophic system results, in the tritrophic microcosms, Pseudomicrothorax was able to survive up to the end of the experiment (Fig. 3d). We expected that the effect of predation would be, to some extent, compensated by the fact that Pseudomicrothorax was able to feed on the cyanobacteria and therefore to proliferate (Fig. 1), but its usage of cyanobacteria clumps as refuges was a surprise.

Many small aquatic organisms are known for their encystment ability, regarded as a way to survive unfavourable environmental conditions, such as starvation, dryness or changes in environment chemistry (Gutiérrez et al. 2001, Müller 2007). In some cases, 

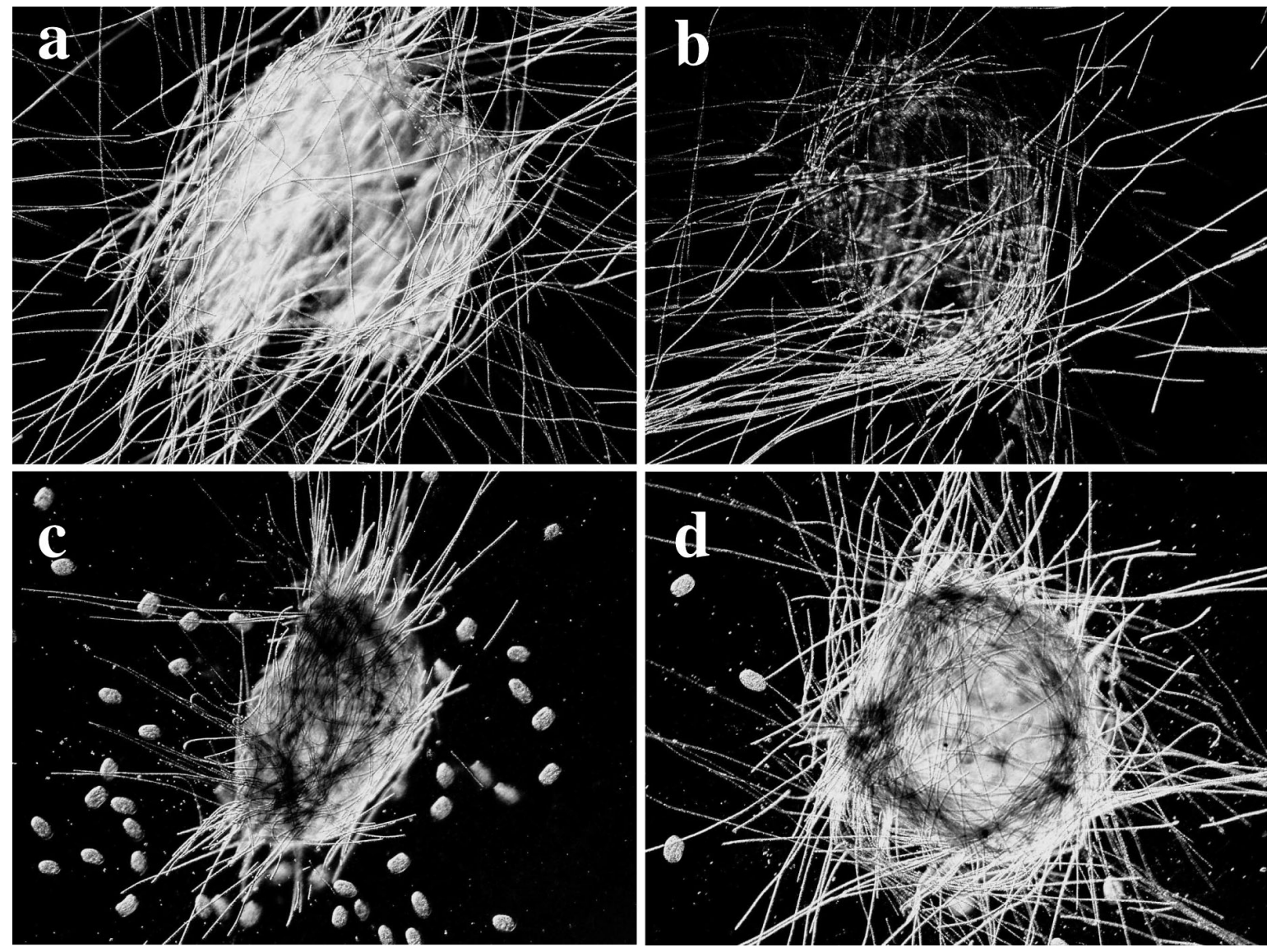

Fig. 3. Phormidium mat after Day 7 of the experiment in (a) the control, and under pressure from (b) Homalozoon, (c) Pseudomicrothorax and (d) both ciliates. Note numerous Pseudomicrothorax in refuges created by the cyanobacteria filaments (d)

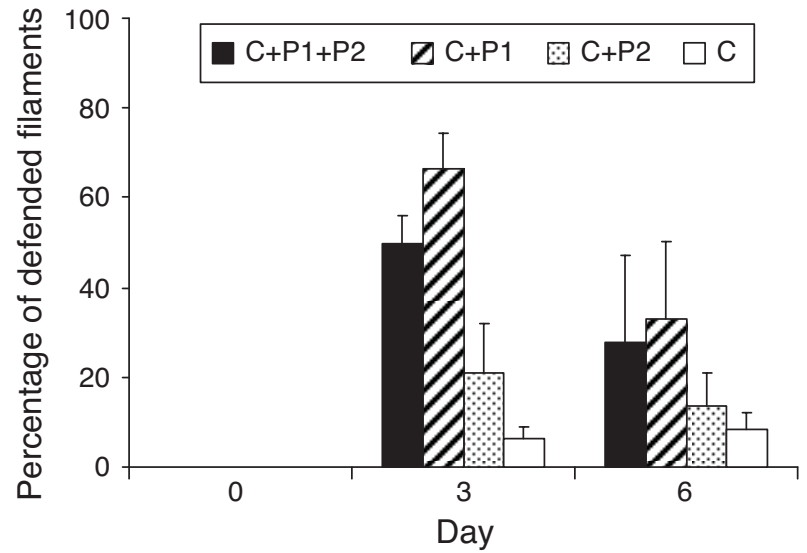

Fig. 4. Phormidium sp. Mean $(+\mathrm{SD})$ percentage of defended cyanobacterial filaments observed in all treatments during the experiment. Treatments: P1: Pseudomicrothorax, P2: Homalozoon, C: Phormidium

encystment was reported to be a predator-mediated defence (Rengefors et al. 1998, Fyda et al. 2005). Fyda et al. (2005) noted that the ciliate Euplotes muscorum showed a higher rate of encystation in the presence of its predators; however, our results did not indicate pre- dation as a factor responsible for Pseudomicrothorax encystment. Apparently, even if Pseudomicrothorax encystment was strengthened by predatory pressure, it was insufficient as a defence against Homalozoon. In the bitrophic $(\mathrm{P} 1+\mathrm{P} 2)$ microcosms, the number of full cysts was extremely low during the experiment (Fig. 2a), and the majority of prey was eaten by predators. However, as shown in Fig. 2b, a few empty cysts were noticed on the second and sixth days in this treatment, which means that ciliate prey left the cysts in spite of the predators' presence. The numbers of cysts in the tritrophic treatment and in the treatment where only Pseudomicrothorax and Phormidium were present $(\mathrm{C}+\mathrm{P} 1)$ remained at the same level throughout the experiment. Therefore, it seems that Pseudomicrothorax encystment was caused by the lack of edible cyanobacterial filaments, the result of the Phormidium induced defence, rather than by the presence of predators. What is interesting is that almost all active ciliates remained satiated while the number of cysts was increasing. This could be explained as a control of active ciliate density by encystment. As a consequence of decreased density of active ciliates and thus grazer 
Table 2. The results of repeated-measures ANOVA showing the effects of Homalozoon (P2) and Pseudomicrothorax (P1) absence/presence on the number of Phormidium (C) filaments defended by a polysaccharide envelope during the time $(\mathrm{T})$ of the experiment. Significant results are given in bold

\begin{tabular}{|llcccc|}
\hline & Source of variation & $\mathrm{df}$ & $\mathrm{SS}$ & $F$ & $\mathrm{p}$ \\
\hline $\begin{array}{l}\text { Phormidium } \\
\text { defended }\end{array}$ & Between-treatments & & & & \\
filaments & Homalozoon & 1 & 13.80 & 0.0253 & 0.876 \\
& Pseudomicrothorax & 1 & 10616.59 & 19.459 & $<\mathbf{0 . 0 0 1}$ \\
& C $\times$ P2 & 1 & 881.85 & 1.616 & 0.228 \\
& Error & 12 & 6547.14 & & \\
& Within-treatments & & & & \\
& Time (T) & 2 & 3011.19 & 10.499 & $<\mathbf{0 . 0 0 1}$ \\
& T $\times$ P2 & 2 & 6.25 & 0.022 & 0.098 \\
& $\mathrm{~T} \times \mathrm{C}$ & 2 & 1350.60 & 4.709 & $<\mathbf{0 . 0 2}$ \\
& $\mathrm{T} \times \mathrm{P} 2 \times \mathrm{P} 1$ & 2 & 307.43 & 1.072 & 0.358 \\
& Error $(\mathrm{T})$ & 24 & 3441.78 & & \\
\hline
\end{tabular}

2002). Our observations strongly support the results obtained by Fiałkowska \& Pajdak-Stós (2002), in that Phormidium adapts its induced defence to grazer pressure and density. During the first $3 \mathrm{~d}$ of the experiment, strong pressure from Pseudomicrothorax induced a strong defence reaction in Phormidium filaments. Induced prey defence can stabilise and reduce the oscillations of predatorprey populations, and this effect was reinforced in the case of Phormidium by the refuges created by cyanobacterial filaments. Recent studies have indicated that predator-induced defence promotes population persistence in tritrophic food chains (Vos et al. 2004a, 2004b), prevents high amplitude predator-prey fluctuapressure, cyanobacterium trichomes leave their shelter (Fiałkowska \& Pajdak-Stós 2002, Fyda et al. 2009). The fact that empty cysts were noticeable in all treatments with Pseudomicrothorax, starting on the second day, indicates that excystment takes place regardless of predator presence (Fig. 2b). In treatments with Phormidium, it might be the reaction of ciliates to the slowly increasing accessibility of food. However, why the prey ciliates leave the cysts when there is a predator in the habitat and no food is available remains unexplained. Possibly, ciliates in cysts are unable to monitor predator presence in the environment and leave cysts at random.

\section{Effects of Pseudomicrothorax on induced defence in Phormidium}

In the aquatic environment, predator-induced defence can be a factor that strongly influences predator-prey oscillations (Kusch 1998, Tollrian \& Harvell 1999, Vos et al. 2004a, Van der Stap et al. 2007a, 2008). Prey that are able to undergo predator-induced morphological changes in unpredictable aquatic environments have a better opportunity to survive in the presence of the predator than an undefended morphotype (Wicklow 1997, Fyda \& Wiąckowski 1998, Van der Stap et al. 2007b). Although the induced defence is energetically more costly than the constitutive form, it is very effective, especially when prey can adjust the extent of their reaction to the real predatory threat (Tollrian \& Harvell 1999). This has been thoroughly studied in several ciliates from the genera Euplotes, Colpidium and Coleps (Kuhlmann \& Heckmann 1985, Fyda \& Wiąckowski 1998, Wickham \& Gugenberger 2008) as well as in green algae (Lürling \& Van Donk 1996) and cyanobacteria (Fiałkowska \& Pajdak-Stós tions and stabilises community dynamics (Verschoor et al. 2004, Vos et al. 2004a, Altwegg et al. 2006, Van der Stap et al. 2007a,b), as well as increasing the relative importance of bottom-up control (Vos et al. 2004b). The results of our work support these hypotheses.

It is worth stressing that our experiment showed that bottom-up control can strongly override top-down control in some cases. Homalozoon quickly eliminates Pseudomicrothorax in a bitrophic system, but in the presence of Phormidium, the influence of the top predator on the prey population is very weak.

The number of dead Pseudomicrothorax cells, very similar in treatments with and without the predator, indicated low Homalozoon pressure. Homalozoon survived to the end of the experiment in numbers similar to its initial abundance. The results described by Fyda et al. (2009) showed that a top predator (Chaetogaster) is able to strongly control an undefended cyanobacteria grazer, whereas defended Euplotes survive under predatory pressure. This might have resulted from the reaction of Phormidium - in Fyda et al. (2009), the grazers were eliminated quickly enough to let the filaments disperse on the well bottoms. In the present study, the induced defence of Phormidium offered good shelter for ciliates grazing on Phormidium.

The observed equilibrium between cyanobacteria and active ciliates was possible because of grazer density-dependent inducible defence in cyanobacteria on the one hand, and the ability of Pseudomicrothorax to react to this form of defence by means of rapid encystment on the other. The top predator effect on this equilibrium turned out to be negligible because of the ability of Pseudomicrothorax to use clumps of cyanobacterial mats as refuges.

Our simple microcosm experiment shows how sophisticated mechanisms can be involved in the interaction between trophic levels. However, we should be 
very careful when extrapolating the results from bitrophic experiments to the natural biocenosis. Additional laboratory experiments and data from field studies are needed to reveal and explain the links among different components of microbial food webs.

Acknowledgements. We thank Prof. Dr. hab. J. Kozłowski, Dr. hab. W. Fiałkowski and Dr. M. Czarnołeski for constructive criticism of the previous version of the manuscript. We also thank the anonymous referees, whose comments greatly improved this article. This work was financially supported by Jagiellonian University DS/WBiNoZ/INoŚ/756.

\section{LITERATURE CITED}

Altwegg R, Eng M, Caspersen S, Anholt BR (2006) Functional response and prey defence level in an experimental predator-prey system. Evol Ecol Res 8:115-128

Balčiünas D, Lawler SP (1995) Effects of basal resources, predation, and alternative prey in microcosm food chains. Ecology 76:1327-1336

Baumberg D, Hausmann K (2007) Vesiculation of food vacuoles and segregation of ingesta: peculiarities of the digestive cycle in the raptorial ciliate Homalozoon vermiculare. Acta Protozool 46:1-8

Bohannan BJM, Lenski RE (1997) Effect of resource enrichment on a chemostat community of bacteria and bacteriophage. Ecology 78:2303-2315

Bohannan BJM, Lenski RE (2000) Linking genetic change to community evolution: insights from studies of bacteria and bacteriophage. Ecol Lett 3:362-377

Brett MT, Goldman CR (1996) A meta-analysis of the freshwater trophic cascade. Proc Natl Acad Sci USA 93:7723-7726

Chase JM, Abrams PA, Grover JP, Diehl S and others (2002) The interaction between predation and competition: a review and synthesis. Ecol Lett 5:302-315

Fiałkowska E, Pajdak-Stós A (1997) Inducible defense against a ciliate grazer, Pseudomicrothorax dubius, in two strains of Phormidium (cyanobacteria). Proc Biol Sci 264:937-941

Fiałkowska E, Pajdak-Stós A (2002) Dependence of cyanobacteria defense mode on grazer pressure. Aquat Microb Ecol 27:149-157

Foissner W, Berger H, Blattere H, Kohmann F (1995) Taxonomische und ökologische Revision der Ciliaten des Saprobiensystems. Band IV: Gymnostomatea, Loxodes, Suctoria. Informationsberichte des Bayer. Landesamtes für Wasserwirtschaft, München, 1/95

Fyda J (1998) Predator-induced morphological changes in the ciliate Colpidium (Protozoa, Ciliophora). Eur J Protistol 34:111-117

Fyda J, Wiąckowski K (1998) Benefits and costs of predatorinduced morphological changes in the ciliate Colpidium kleini (Protozoa, Ciliophora). Eur J Protistol 34:118-123

Fyda J, Warren A, Wolińska J (2005) An investigation of predator-induced defense responses in ciliated protozoa. J Nat Hist 39:1431-1442

Fyda J, Nosek J, Wiąckowski K, Pajdak-Stós A, Fiałkowska E (2009) Effects of grazers' species identity on cyanobacteria in bitrophic and tritrophic food webs. FEMS Microbiol Ecol 68:329-339

Gasol JM, Duarte CM (2000) Comparative analyses in aquatic microbial ecology: How far do they go? FEMS Microbiol Ecol 31:99-106

Gause GF (1934) The struggle for existence. Williams and Wilkens, Baltimore, MD
Gomez JM, Zamora R (2002) Thorns as induced mechanical defense in a long-lived shrub (Hormathophylla spinosa, Cruciferae). Ecology 84:885-890

> Gutiérrez JC, Callejas S, Borniquel S, Benítez L, MartínGonzález A (2001) Ciliate cryptobiosis: a microbial strategy against environmental starvation. Int Microbiol 4: 151-157

Halaj J, Wise DH (2002) Impact of a detrital subsidy on trophic cascade in a terrestrial grazing food web. Ecology 83: 3141-3151

Kołaczyk A, Wiąckowski K (1997) Induced defence in the ciliate Euplotes octocarinatus is reduced when alternative preys are available to the predator. Acta Protozool 36: $57-61$

> Křivan V (1998) Effects of optimal antipredator behavior of prey on predator-prey dynamics: the role of refuges. Theor Popul Biol 53:131-142

Kuhlmann HW, Heckmann K (1985) Interspecific morphogens regulating prey-predator relationships in protozoa. Science 227:1347-1349

Kuhlmann HW, Heckmann K (1994) Predation risk of typical ovoid and 'winged' morph of Euplotes (Protozoa, Ciliophora). Hydrobiologia 284:219-227

Kusch J (1995) Adaptation of inducible defense in Euplotes daidaleos (Ciliophora) to predation risks by various predators. Microb Ecol 30:79-88

Kusch J (1998) Long-term effects of inducible defense. Ecoscience $5: 1-7$

Luckinbill LS (1973) Coexistence in laboratory populations of Paramecium aurelia and its predator Didinium nasutum. Ecology 54:1320-1327

Lürling M, Van Donk E (1996) Zooplankton induced unicellcolony transformation in Scenedesmus acutus and the effect on herbivore Daphnia. Oecologia 108:432-437

Müller H (2007) Live observation of excystment in the spirotrich ciliate Meseres corlissi. Eur J Protistol 43: 95-100

> Pajdak-Stós A, Fiałkowska E, Fyda J (2001) Phormidium autumnale (Cyanobacteria) defense against three ciliate grazer species. Aquat Microb Ecol 23:237-244

> Pinckney JL, Carman KR, Lumsden SE, Hymel SN (2003) Microalgal-meiofaunal trophic relationships in muddy intertidal estuarine sediments. Aquat Microb Ecol 31: 99-108

Rengefors K, Karlsson I, Hansson LA (1998) Algal cyst dormancy: a temporal escape from herbivory. Proc R Soc Lond B Biol Sci 265:1353-1358

> Rosenzweig ML (1971) The paradox of enrichment. Science 171:385-387

Salt GW (1967) Predation in an experimental protozoan population (Woodruffia-Paramecium). Ecol Monogr 37: 113-144

Samuelsson K, Andersson A (2003) Predation limitation in the pelagic microbial food web in an oligotrophic aquatic system. Aquat Microb Ecol 30:239-250

Shurin JB, Borer ET, Seabloom EW, Anderson K and others (2002) A cross-ecosystem comparison of the strength of trophic cascades. Ecol Lett 5:785-791

Shurin JB, Gruner DS, Hillebrand H (2006) All wet or dried up? Real differences between aquatic and terrestrial food webs. Proc R Soc Lond B Biol Sci 273:1-9

Sokal RR, Rohlf FJ (1981) Biometry. W.H. Freeman, New York

Stanier RY, Kunisawa R, Mandel M, Cohen-Bazire G (1971) Purification and properties of unicellulare blue-green algae (order Chroococcales). Bacteriol Rev 35:171-205

Steiner ChF (2001) The effects of prey heterogeneity and consumer identity on the limitation of trophic-level biomass. 
Ecology 82:2495-2506

Strom S (2002) Novel interactions between phytoplankton and microzooplankton: Their influence on the coupling between growth and grazing rates in the sea. Hydrobiologia 480:41-54

Tollrian R, Harvell CD (1999) The ecology and evolution of inducible defenses. Princeton University Press, Princeton, NJ

> Van der Stap I, Vos M, Mooij WM (2006) Linking herbivoreinduced defences to population dynamics. Freshw Biol 51: 424-434

Van der Stap I, Vos M, Mooij WM (2007a) Inducible defenses and rotifer food chain dynamics. Hydrobiologia 593: 103-110

Van der Stap I, Vos M, Verschoor AM, Helmsing NR, Mooij WM (2007b) Induced defenses in herbivores and plants differentially modulate a trophic cascade. Ecology 88: $2474-2481$

Van der Stap I, Vos M, Tollrian R, Mooij WM (2008) Inducible defenses, competition and shared predation in planktonic food chains. Oecologia 157:697-705

Veilleux BG (1979) An analysis of the predatory interaction between Paramecium and Didinium. J Anim Ecol 48: $787-803$

Editorial responsibility: Klaus Jürgens, Rostock, Germany
Ventelä AM, Wiakowski K, Moilanen M, Saarikari V, Vuorio K, Sarvala J (2002) The effect of small zooplankton on the microbial loop and edible algae during a cyanobacterial bloom. Freshw Biol 47:1807-1819

- Verschoor AM, Vos M, Van der Stap I (2004) Inducible defences prevent strong population fluctuations in bi- and tritrophic food chains. Ecol Lett 7:1143-1148

Vos M, Verschoor AM, Kooi BW, De Angelis DL, Mooij WM (2004a) Inducible defenses and trophic structure. Ecology 85:2783-2794

Vos M, Kooi BW, De Angelis DL, Mooij WM (2004b) Inducible defences and the paradox of enrichment. Oikos 105:471-480

Wiąckowski K, Mentel AM, Moilanen M, Saarikari V, Vuorio K, Sarvala J (2001) What factors control planktonic ciliates during summer in a highly eutrophic lake? Hydrobiologia 443:43-57

Wickham SA, Gugenberger E (2008) Evaluating inducible morphological defences in the common freshwater ciliate, Coleps hirtus. J Plankton Res 30:1315-1321

- Wicklow BJ (1997) Signal-induced defensive phenotypic changes in ciliate protists: morphological and ecological implications for predator and prey. J Eukaryot Microbiol 44:176-188

Submitted: July 15, 2009; Accepted: November 16, 2009

Proofs received from author(s): February 3, 2010 